\title{
Energy partition for maintenance and weight gain in Nellore and crossbred steers finished under grazing ${ }^{1}$
}

\section{Nivaldo de Faria Sant' Ana $^{2}$, Carlos Augusto de Alencar Fontes ${ }^{2}$, Elizabeth Fonsêca Processi ${ }^{2}$ João Gomes de Siqueira ${ }^{2}$, Alberto Magno Fernandes ${ }^{2}$, Carlos Eugênio Martins ${ }^{3}$}

\author{
1 Projeto de pesquisa financiado com recursos obtidos juntos ao CNPq - Edital Universal 2006 e FAPERJ - Edital $n^{\circ} 19 / 2008$ \\ 2 Universidade Estadual do Norte Fluminense - UENF. \\ ${ }^{3}$ Embrapa Gado de Leite.
}

ABSTRACT - The objective of this work was to estimate net energy $\left(\mathrm{NE}_{\mathrm{m}}\right)$ and metabolizable energy $\left(\mathrm{ME}_{\mathrm{m}}\right)$ requirements for maintenance and efficiency of use of metabolizable energy for maintanence $\left(\mathrm{k}_{\mathrm{m}}\right)$ and gain $\left(\mathrm{k}_{\mathrm{g}}\right)$ of grazing Nellore and crossbred steers. It was used 24 castrated steers, 12 Nellore breed (386 kg SBW) and 12 1/2 Limousin-Nelore crossbred (397 kg SBW). The comparative slaughter method was used. In each genetic group, animals were grouped in three similar groups: reference; restrict feeding and ad libitum feeding. The reference group was slaughtered in the beginning of the experiment whereas the others were slaughtered at the end of it. During the 104 days of the experimental period, the group under restrict feeding had access to pastures for 3.5 hours daily whereas the group with ad libitum feeding remained on pasture full time. Forage intake was estimated in two trials by using the double-indicator method. Values of $\mathrm{NE}_{\mathrm{m}}$, $\mathrm{ME}_{\mathrm{m}}$, $\mathrm{k}_{\mathrm{m}}$ and $\mathrm{k}_{\mathrm{g}}$ were estimated on the basis of empty body weight (EBW) through linear and non-linear model fitting. Requirements of $\mathrm{NE}_{\mathrm{m}}$ and $\mathrm{ME}_{\mathrm{m}}$ did not differ among Nellore and crossbred animals. In the linear model, the following results were obtained: Requirements of $\mathrm{NE}_{\mathrm{m}}=86 \mathrm{kcal} / \mathrm{kg}^{0.75}$; requirements of $\mathrm{ME}_{\mathrm{m}}=136 \mathrm{kcal} / \mathrm{kg}^{0.75}$ and $\mathrm{k}_{\mathrm{m}}=0.63 . \mathrm{K}_{\mathrm{g}}$ value was higher for Nellore animals (0.39) than for crossbred animals $\left(\mathrm{k}_{\mathrm{g}}=0.33\right)$. Requirement of net energy of maintenance does not differ among grazing Nellores and $1 / 2$ European-Nellore crossbred. For the same body weight, Nellore animals present greater fat proportion in gain composition than $1 / 2$ European-Nelore crossbred.

Key Words: Limousin, Mombasa grass

\section{Partição de energia para mantença e ganho em novilhos nelores e mestiços terminados a pasto}

\begin{abstract}
RESUMO - Este trabalho foi conduzido com o objetivo de estimar as exigências de energia líquida $\left(\mathrm{EL}_{\mathrm{m}}\right)$ e metabolizável $\left(E M_{m}\right)$ para mantença e as eficiências de utilização da energia metabolizável para mantença $\left(k_{m}\right)$ e ganho $\left(k_{g}\right)$ de novilhos nelores e mestiços a pasto. Foram utilizados 24 novilhos castrados, sendo 12 da raça Nelore (386 kg PCJ) e 12 mestiços 1/2 LimousinNelore (397 kg PCJ). Foi utilizado o método do abate comparativo. Em cada grupo genético, os animais foram divididos em três grupos semelhantes: referência; alimentação restrita; e alimentação à vontade. O grupo-referência foi abatido no início do experimento, enquanto os demais foram abatidos ao término do experimento. Durante os 104 dias do período experimental, o grupo sob restrição alimentar teve acesso à pastagem por 3,5 horas diárias, enquanto o grupo com alimentação à vontade permaneceu na pastagem em tempo integral. O consumo de forragem foi estimado em dois ensaios utilizando-se a técnica do duplo indicador. Os valores de $\mathrm{EL}_{\mathrm{m}}, \mathrm{EM}_{\mathrm{m}}, \mathrm{k}_{\mathrm{m}}$ e $\mathrm{k}_{\mathrm{g}}$ foram estimados com base no peso de corpo vazio (PVZ), por meio do ajuste de modelos lineares e não-lineares. As exigências de $\mathrm{EL}_{\mathrm{m}}$ e $\mathrm{EM}_{\mathrm{m}}$ não diferiram entre os animais Nelore e mestiços. No modelo linear, foram obtidos os seguintes resultados: exigência de $\mathrm{EL}_{\mathrm{m}}=86 \mathrm{kcal} / \mathrm{kg}^{0.75}$; exigência de $\mathrm{EM}_{\mathrm{m}}=136 \mathrm{kcal} / \mathrm{kg}^{0.75}$; e $\mathrm{k}_{\mathrm{m}}=0,63$. O valor de $\mathrm{k}_{\mathrm{g}}$ foi maior para animais Nelore $(0,39)$ que para mestiços $\left(\mathrm{k}_{\mathrm{g}}=0,33\right)$ A exigência de energia líquida de mantença não difere entre nelores e mestiços 1/2Europeu-Nelore em regime de pastejo. A um mesmo peso corporal, nelores apresentam maior proporção de gordura na composição do ganho que mestiços 1/2Europeu-Nelore.
\end{abstract}

Palavras-chave: capim-mombaça, Limousin

\section{Introduction}

The validity of the unrestricted use of foreign systems of feeding beef cattle has not been demonstrated in Brazil, yet. Points of inadequate nutritional requirements of animals and/or the nutritional value of foods were reported by authors who compared the results predicted by these systems to those observed in the 
Brazilian productive conditions (Detmann et al., 2004; Gesualdi Jr. et al., 2005).

The feeding systems for beef cattle are largely based on tables and empirical equations developed in the productives conditions (animal breed, feed used) of the country of origin or similar (CSIRO, 1990, NRC, 2000; Fox et al., 2004).

In Brazil, several studies have been conducted to assess the nutritional requirements of beef cattle. The amount of information has enabled the compilation and analysis of large numbers of results, leading to equations and/or values probably more reliable and representative of the national herd (Fontes, 1995; Henrique et al., 2005). However, almost all the Brazilian studies on the energy requirements of cattle were conducted under confinement conditions, thus exist a great need for informations about grazed animals (Fontes et al., 2005a,b).

Accordingly, the comparison among the energy requirements of different genetic groups in tropical pastures, particularly with the inclusion of Nellore breed, would be particularly relevant. The equivalence of performance between breeds with different yield potentials has been attributed to the effect of genotype $x$ environment interaction, which also could have an impact on energy requirements for animals maintenance (Johnson et al. 1990; Jenkins \& Ferrell, 1994).

This study was conducted to evaluate the partition of energy for maintenance and gain of Nellore and crossbred steers under grazing.

\section{Material and Methods}

The research was conducted in Campos dos Goytacazes (Brazil, $21^{\circ} 42^{\prime}$ S, $41^{\circ} 19^{\prime} \mathrm{W}, 13 \mathrm{~m}$ altitude) during the rainy season (December-April) and it lasted 104 days. It was used an experimental area of 6.5 ha, flat terrain, cultivated with Mombasa grass (Panicum maximum cv. Mombaça) and divided with electric fences into 13 paddocks of 0.5 ha each.

The pasture was managed under rotational stocking with periods of grazing and rest of 2 and 24 days, respectively. During the experimental period, four 26-day grazing cycles were completed. The daily herbage allowance was maintained at around $8 \mathrm{~kg}$ of green leaves dry matter (DM) per $100 \mathrm{~kg}$ body weight (BW), using similar put and take steers.

Biomass of green leaves was estimated the day before the start of grazing in paddocks representative of the experimental area, according to methodology described by Ribeiro et al. (2008). Maintenance fertilization was $80 \mathrm{~kg} / \mathrm{ha}$ of nitrogen, split into two equal applications of ammonium sulfate.
The experimental animals were 24 steers: 12 Nellore and 12 crossbred 1/2Limousin-Nellore, with an average shrunk body weight (SBW) of $386 \pm 3.8$ and $397 \pm 9.7 \mathrm{~kg}$, respectively. The steers were purchased from the same commercial breeder in the region, constituting a homogeneous portion within each genetic group. In the three weeks preceding the experimental period, animals were identified, subjected to the control of endo and ectoparasites and adapted to pastures and to the experimental management.

The partition of energy for maintenance and gain was measured by comparative slaughter method, described by Lofgreen \& Garrett (1968) and adapted for grazing animals by Fontes et al. (2005a). Within each genetic group, the animals were grouped randomly into three groups of four animals: reference, restricted feeding, and ad libitum feeding.

The reference group was slaughtered at the beginning of the experimental period. During the experimental period, the animals under restricted feeding had access to pasture for 3.5 hours daily (from 8:30 a.m. to 12:00 p.m.), and the rest of the day they were kept in covered individual pens $\left(12 \mathrm{~m}^{2}\right)$ with drinker, $100 \mathrm{~m}$ away from the pasture. The objective of this management was to maintain the intake of restricted animals close to the requirement for maintenance (Fontes et al., 2005a). Animals fed ad libitum were kept on pasture throughout the day.

Animals on restricted and ad libitum feeding, from both genetic groups, were kept together in the pasture, taken to same the paddocks daily. In the pasture, they had access to shade, water and commercial mineral mixture. The SBW was recorded at the beginning and after each grazing cycle, after 16 hours without food and water. At the end of the experimental period, all animals from both groups were slaughtered.

Slaughter was carried out in a commercial slaughterhouse, according to federal standards prescribed for the humane slaughter of cattle (Brazil, 2000). After slaughter, all the body parts were weighed, collected, processed and representative samples of organs and tissues of the carcass (Section $\mathrm{HH}$ ) and non-carcass were analyzed for determination of the body content of fat, protein, ash and water of each animal. A detailed description of this procedure can be found in Sant'Ana et al. (2011).

The energy content (Mcal) in the empty body of each animal was estimated from the body content of protein and fat and their caloric equivalents (ARC, 1980): $5.6405 \mathrm{kcal} / \mathrm{g}$ (protein) and $9.3929 \mathrm{kcal} / \mathrm{g}$ (fat).

For the animals slaughtered at the beginning of the experimental period (reference group), the mean ratio SBW/ EBW and body energy content (kcal/g EBW) were calculated 
within each breed group, which were used to predict the EBW and energy content and body of animals under restricted and ad libitum feeding at the beginning of the experimental period. The energy retained during the experimental period in the body of each animal was calculated as the difference between the final body energy and initial body energy, which was predicted from the reference group.

Forage intake was estimated in two trials during the experimental period by using the double indicator method (Smith \& Reid, 1955). LIPE ${ }^{\circledR}$ (hidroxiphenilpropan modified and enriched) and lignin in $\mathrm{H}_{2} \mathrm{SO}_{4}$ were used as external and internal indicator, respectively. In each experiment, a capsule containing $500 \mathrm{mg}$ of LIPE $^{\circledR}$ was administrated orally for each animal for seven days, once daily at 12:00 p.m. In the last four days, it was also collected stool samples, from rectum of the animals, simultaneously with the supply of the indicator. The gelatin capsules containing the LIPE ${ }^{\circledR}$ were wrapped in paper to prevent losses by regurgitation. Forage samples were collected (hand plucking technique) daily from the paddocks occupied by the animals during the estimation of intake.

The individual samples of stool and forage were dried at $55^{\circ} \mathrm{C}$ and ground to $1 \mathrm{~mm}$. After that, 64 samples of feces (per animal, per paddock and trial) and eight samples of forage (for picket and trial) were made proportionally to the dry weight. The samples of stool and feed were analyzed for $\mathrm{DM}\left(105^{\circ} \mathrm{C}\right)$, gross energy (calorimetric bomb) and lignin in $\mathrm{H}_{2} \mathrm{SO}_{4}$ (Silva \& Queiroz, 2002). Thus, it was possible to estimate the concentration of digestible energy (DE) of forage for each animal. Simultaneously, the forage samples were analyzed for in vitro DM digestibility (Silva \& Queiroz, 2002).

The samples of stool were also analyzed for LIPE ${ }^{\circledR}$ content (Saliba et al., 2003), to estimate the stool output. The concentration of metabolizable energy (ME) in forage was obtained by using the relationship: $\mathrm{ME}=0.82 \times \mathrm{DE}$ (NRC, 2000).

From the results obtained in the two trial of predictive intake, it was calculated the average of daily individual metabolizable energy intake (MEI). The difference between energy consumed and energy retained (RE) corresponded to heat production (HE) or HE = MEI - RE (NRC, 2000). The average of daily individual values of MEI, RE and HE were expressed in $\mathrm{kcal} / \mathrm{kg}^{0.75} \mathrm{EBW} /$ day.

In order to estimate the net energy for maintenance (NEm), it was adjusted the linear equation proposed by Lofgreen \& Garrett (1968):

$\log _{10} \mathrm{HE}=\alpha+\gamma \times \mathrm{MEI}$

(equation 1)

where $\mathrm{NE}_{\mathrm{m}}=10^{\alpha}$
In order to estimate the $\mathrm{ME}$ for maintenance $\left(\mathrm{ME}_{\mathrm{m}}\right)$ and the efficiency of utilization of ME for maintenance $\left(\mathrm{k}_{\mathrm{m}}\right)$ and gain $\left(\mathrm{k}_{\mathrm{g}}\right)$, the following equation was adjusted (Lofgreen \& Garrett, 1968):

$\mathrm{RE}=\delta+\varsigma \times$ MEI

where $\mathrm{k}_{\mathrm{g}}=\varsigma$ and, assuming $\delta=\mathrm{NE}_{\mathrm{m}} \times \mathrm{k}_{\mathrm{g}} / \mathrm{k}_{\mathrm{m}}$ (NRC, 1981), then $\mathrm{ME}_{\mathrm{m}}=-\delta / \varsigma$ and $\mathrm{k}_{\mathrm{m}}=\mathrm{NE}_{\mathrm{m}} / \mathrm{ME}_{\mathrm{m}}$.

The net energy concentrations in forage for maintenance $\left(\left[\mathrm{NE}_{\mathrm{m}}\right]\right)$ and gain $\left(\left[\mathrm{NE}_{\mathrm{g}}\right]\right)$ were calculated according to $\mathrm{NRC}(2000):\left[\mathrm{NE}_{\mathrm{m}}\right]=[\mathrm{ME}] \times \mathrm{k}_{\mathrm{m}}$, and $\left[\mathrm{NE}_{\mathrm{g}}\right]=$ $[\mathrm{ME}] \times \mathrm{k}_{\mathrm{g}}$.

In addition, with the objective of verifying the equivalence of results, the energy efficiency and requirements for maintenance $\left(\mathrm{NE}_{\mathrm{m}}, \mathrm{ME}_{\mathrm{m}}\right.$ and $\mathrm{k}_{\mathrm{m}}$ ) were also estimated without logarithmic transformation, using directly the nonlinear equation proposed by NRC (1981), applying the constraint $\zeta+\theta \times \mathrm{ME}_{\mathrm{m}}=0$ (Henrique et al., 2005):

$\mathrm{HE}=\zeta \times \exp .(\theta \times \mathrm{MEI})$

(equation 3) where $\mathrm{NE}_{\mathrm{m}}=\zeta$

By substituting the parameters by their estimates $(\hat{\zeta}, \hat{\theta})$ in equation 3, the $\mathrm{ME}_{\mathrm{m}}$ corresponded to the value of MEI when HE/MEI $=1.000(\mathrm{ER}=0.000)$. The value of $\mathrm{k}_{\mathrm{m}}$ was equal to the quotient $\mathrm{NE}_{\mathrm{m}} / \mathrm{ME}_{\mathrm{m}}$.

The linear regression equations (equations 1 and 2) were adjusted by using PROC REG of SAS ${ }^{\circledR}$ statistical package. The breed effect was tested by using the general model:

$$
\mathrm{Y}_{\mathrm{i}}=\beta_{0}+\beta_{1} \mathrm{X} 1_{\mathrm{i}}+\beta_{2} \mathrm{X} 2_{\mathrm{i}}+\beta_{3} \mathrm{X} 1_{\mathrm{i}} \mathrm{X} 2_{\mathrm{i}}+\varepsilon_{\mathrm{i}} \text {, }
$$

for observations $\mathrm{i}=1,2, \ldots$, n, where $Y_{i}=$ dependent variable (HE, RE); $\mathrm{X} 1_{\mathrm{i}}=$ quantitative variable $(\mathrm{MEI}) ; \mathrm{X} 2_{\mathrm{i}}=$ qualitative variable "dummy", with values 0 for Nellore $\left(Y_{i}=\beta_{0}+\beta_{1} X 1_{i}\right)$ and 1 for crossbred $\left(Y_{i}=\left(\beta_{0}+\beta_{2}\right)+\left(\beta_{1}+\beta_{3}\right) X 1_{i}\right)$; $\mathrm{X} 1_{\mathrm{i}} \mathrm{X} 2_{\mathrm{i}}=$ interaction effect; and $\varepsilon_{\mathrm{i}}=$ random error (which was allowed as an additive even with the logarithmic transformation of equation 1 ).

If $\beta_{3} \neq 0$, the genetic groups differed on the regression coefficient; if $\beta_{2} \neq 0$, the genetic groups differed on the intercept; and if $\beta_{2}=0$ and $\beta_{3}=0$, there was no difference between the coefficients and intercepts, and only one equation was adjusted, considering the results of both genetic groups together. The null hypothesis for the parameter estimates $\left(\mathrm{H} 0: \hat{\beta}_{0}=0, \hat{\beta}_{1}=0, \hat{\beta}_{2}=0, \hat{\beta}_{3}=0\right)$ were tested by the $t$ test (5\%).

The equation of nonlinear regression (equation 3 ) was adjusted using PROC NLIN of the SAS ${ }^{\circledR}$ statistical package, using the method MARQUARDT.

\section{Results and Discussion}

The estimated parameters $\beta_{2}$ and $\beta_{3}$ obtained by fitting the linear model $\mathrm{BW} \times \mathrm{MEI}$ were not different from zero 
(Table 1), and this indicates that the intercept and regression coefficient did not differ among the genetic groups. Setting an intercept common to the two genetic groups, resulted in a single value of $\mathrm{NE}_{\mathrm{m}}$ for Nellore and crossbred (Table 2).

For the model RE $\times$ MEI, the estimated parameter $\beta_{2}$ did not differ $(\mathrm{P}>0.05)$ and $\beta_{3}$ was higher $(\mathrm{P}<0.05)$ than zero (Table 1). Thus, for each genetic group, it was set a different equation, with the value of $\mathrm{k}_{\mathrm{g}}$ (regression coefficient) higher for Nellore compared to crossbreed (Table 2).

The adjustment of non-linear model BW $\times$ MEI, with the restrictions proposed by Henrique et al. (2005), resulted in estimated values for $\mathrm{NE}_{\mathrm{m}} \mathrm{ME}_{\mathrm{m}}$ slightly higher than those obtained by the linear model (Table 1). The same trend was observed by Siqueira et al. (2007).

The relationship between the maintenance requirements for Bos indicus and Bos taurus remains controversial. According to the energy feeding systems CSIRO (1990) and NRC (2000), Bos taurus cattle and their crosses have a higher net energy requirements for maintenance than Bos indicus. However, the CNCPS (Fox et al., 2004) does not recognize differences in the net energy requirement for maintenance between Nellore and Limousin breeds. The recommendation of CNCPS is based partly on research with Nellore cattle conducted in Brazil (Tedeschi et al., 2002).

From the review of Brazilian studies with evaluation of Bos taurus and their crosses, Henrique et al. (2005) reported

Table 1 - Estimated parameters obtained in fits of linear models

\begin{tabular}{lrcc}
\hline Parameter & Estimate & Standard error & $\mathrm{P}<$ \\
\hline$\beta_{0}$ & 1.9315 & $\log 10 \mathrm{HE}=\alpha+\gamma \times$ MEI \\
$\beta_{1}$ & 0.0015 & 0.0103 & 0.0001 \\
$\beta_{2}$ & 0.0109 & 0.00004 & 0.0001 \\
$\beta_{3}$ & -0.0000 & 0.0152 & 0.1465 \\
& & 0.00005 & 0.1973 \\
$\beta_{0}$ & -53.8658 & $\mathrm{RE}=\delta+\varsigma \times$ MEI \\
$\beta_{1}$ & 0.3959 & 0.4351 & 0.0001 \\
$\beta_{2}$ & 9.2860 & 0.0019 & 0.0001 \\
$\beta_{3}$ & -0.0661 & 12.4188 & 0.4695 \\
\hline
\end{tabular}

the value of $73 \mathrm{kcal} / \mathrm{kg}^{0.75} \mathrm{EBW}$ for the $\mathrm{NE}_{\mathrm{m}}$ requirement. This value is within the confidence interval of 95\% (72 to 82) for the estimate $77 \mathrm{kcal} / \mathrm{kg}^{0.75} \mathrm{EBW}$ observed for Bos taurus by Lofgreen \& Garrett (1968) and adopted by the NRC (2000). Bos taurus, Bos indicus and crossbred cattle also did not differ in $\mathrm{NE}_{\mathrm{m}}$ requirement in works conducted by Ferrell \& Jenkins (1998), Freitas et al. (2006) and Siqueira et al. (2007).

Differences in energy requirements for maintenance, within and between breeds, have been partly attributed to the size of the internal organs (Garrett, 1980; Dicostanzo et al. 1990; Ferrell \& Jenkins, 1998). The organs have high metabolic activity and the liver and gastrointestinal tract account for an average of 45 to $50 \%$ of heat production in ruminant animals (Johnson et al., 1990). This high energy expenditure would be associated with protein turnover (Garrett, 1980). The size of these organs and the energy requirements for maintenance of the animal get higher in response to increased energy intake (Johnson et al., 1990).

Thus, under non-limiting conditions, high productive potential animals have higher energy intake, organ size and energy requirements for maintenance higher in comparison to animals of lower potential. However, under nutrient limiting conditions, the energy requirement would not differ between animals of different yield potentials (Johnson et al. 1990; Ferrell \& Jenkins, 1998; NRC, 2000).

Generally, pastures can be considered limiting environments, particularly the tropical ones. Even pasture intensive production systems provide moderate individual performances compared to confinement with high energy density diets (Owens et al. 1995; Poppi \& Mclennan, 1995). In this study, the average weights of organs (ad libitum group) were 3.9 versus $4.0 \mathrm{~kg}$ (liver) and 15.4 versus $17.1 \mathrm{~kg}$ (gastrointestinal tract) to crossbred and Nellore, respectively. The low absolute values and the small difference in size of organs among the genetic groups suggest that the level of energy intake may not have been high enough to justify possible differences in maintenance requirements.

Table 2 - Estimates for the parameters of fitted equations and calculated values of requirements and energetic efficiency 1

\begin{tabular}{|c|c|c|c|c|c|c|c|}
\hline & & & $E=\alpha+\gamma$ & & & & \\
\hline Breed & $\alpha$ & $\hat{\gamma}$ & $r^{2}$ & CV (\%) & $\mathrm{NE}_{\mathrm{m}}$ & $\mathrm{ME}_{\mathrm{m}}$ & $\mathrm{k}_{\mathrm{m}}$ \\
\hline Poolled & 1.9329 & 0.0015 & 0.89 & 9.40 & 86 & $136^{111}$ & 0.63 \\
\hline
\end{tabular}

${ }^{1} \mathrm{HE}=$ heat production; MEI = metabolizable energy intake; RE = retained energy. $\mathrm{HE}, \mathrm{MEI}$ and RE are expressed in $\mathrm{kcal} / \mathrm{kg}^{0.75} \mathrm{EBW}$. 
The $\mathrm{NE}_{\mathrm{m}}$ requirement verified in this study $\left(86 \pm 5 \mathrm{kcal} / \mathrm{kg}^{0.75}\right.$ EBW) did not differ from the value of $77 \pm 5 \mathrm{kcal} / \mathrm{kg}^{0.75} \mathrm{EBW}$ observed by Lofgreen \& Garrett (1968) and was higher than the $73 \pm 3 \mathrm{kcal} / \mathrm{kg}^{0.75} \mathrm{EBW}$ obtained by Henrique et al. (2005), considering the overlap of confidence intervals at 95\% $\left(\mathrm{NE}_{\mathrm{m}} \pm\right.$ (standard error $\left.\left.\times t\right)\right)$.

Henrique et al. (2005), compiled the results of studies done on feedlot in Brazil to evaluate the $\mathrm{NE}_{\mathrm{m}}$ requirement of Bos indicus, Bos taurus and crossbred cattle ( $\mathrm{n}=320)$, steers and bulls, by the comparative slaughter method. Lofgreen \& Garrett (1968) based their research on feedlot of Bos taurus steers. A contextualized analysis of these results indicates that the value of $86 \mathrm{kcal} / \mathrm{kg}^{0.75} \mathrm{EBW}$ verified in this work is high, possibly due to the production system (pasture $v$ s feedlot), not because of intrinsic characteristics of animals (breed and sex).

The comparative slaughter method alone does not allow to quantify isolatedly the fasting heat production (FHP). In fact, the $\mathrm{NE}_{\mathrm{m}}$ requirement is made by FHP plus the heat production associated with physical activity of animals (NRC, 1981). Grazing animals would require more energy for physical activities compared with feedlot animals, due to the need, for example, for walking and selection/prehension of food. These activities account for heat production associated with grazing $\left(\mathrm{H}_{\mathrm{g}} \mathrm{P}\right)$; additional energy expenditure relative to feedlot animals, to which $\mathrm{H}_{\mathrm{g}} \mathrm{P}=0$ (CSIRO, 1990; NRC 2000).

However, Fontes et al. (2005a), working with 3/4 GirHolstein steers grazing elephant grass (Pennisetum purpureum), managed under intensive system, obtained the value of $63 \mathrm{kcal} / \mathrm{kg}^{0.75} \mathrm{EBW}$ for $\mathrm{NE}_{\mathrm{m}}$ requirement. These authors suggested that in experimental conditions the $\mathrm{H}_{\mathrm{g}} \mathrm{P}$ was of low magnitude because the pasture had characteristics favorable to grazing. Moreover, Martin and Garcia (1995) reported the value of $90 \mathrm{kcal} / \mathrm{kg}^{0.75} \mathrm{EBW}$ for bulls grazing star grass (Cynodon nlemfuensis).

Estimates for the heat production associated with grazing vary widely in the literature because of several factors which influence the $\mathrm{H}_{\mathrm{g}} \mathrm{P}$ (NRC, 2000). Thus, the $\mathrm{H}_{\mathrm{g}} \mathrm{P}$ would result in increases from 10 to $50 \%$ in energy requirement for maintenance (Mcal/day) of cattle kept on pasture - in comparison to cattle in a feedlot (Osuji, 1974, CSIRO, 1990, NRC 2000). To quantify the $\mathrm{H}_{\mathrm{g}} \mathrm{P}$, the NRC (2000) suggests the equation proposed by CSIRO (1990), which considers the variables: intake, body weight, topography, and availability and digestibility of forage.

By substituting the mean values obtained in this study (body weight $=445 \mathrm{~kg}$; intake $=8.0 \mathrm{~kg} \mathrm{DM} /$ day; experimental area with flat terrain, forage availability $=7.5 \mathrm{t}$ ha, and in vitro digestibility of forage $=0.65$ ) in equation proposed by CSIRO (1990), the value obtained for $\mathrm{H}_{\mathrm{g}} \mathrm{P}$ was equal to $1.79 \mathrm{Mcal} /$ day. In another approach, by subtracting the value of $73 \mathrm{kcal} / \mathrm{kg}^{0.75} \mathrm{EBW}$ - admitted this discussion as a reference for fedlot animlas (Henrinque et al., 2005) from NEm requirement observed in this study $\left(86 \mathrm{kcal} / \mathrm{kg}^{0.75} \mathrm{EBW}\right.$ ) it is possible to estimate the $\mathrm{H}_{\mathrm{g}} \mathrm{P}$ being equal to $1.05 \mathrm{Mcal} /$ day for the experimental animals (average of $350 \mathrm{~kg} \mathrm{EBW}$ ).

The values of 1.05 and $1.79 \mathrm{Mcal} /$ day correspond, respectively, to the increase of 17 and $26 \%$ in maintenance requirements of the experimental animals, with reference to the value of $\mathrm{NE}_{\mathrm{m}}=73 \mathrm{kcal} / \mathrm{kg}^{0.75} \mathrm{EBW}$ (Henrique et al., 2005). These values are consistent with good quality pastures intensively managed, in which the $\mathrm{H}_{\mathrm{g}} \mathrm{P}$ would result in an increase from 10 to $20 \%$ on energy requirements for maintenance of the cattle (Osuji, 1974; CSIRO, 1990).

The efficiency of utilization for maintenance $\left(\mathrm{k}_{\mathrm{m}}\right)$ has a positive relationship with the energy density of the diet (NRC, 1981). The value observed in this study $\left(\mathrm{k}_{\mathrm{m}}=0.63\right)$, common to the two genetic groups, is consistent for forage (ARC, 1980). Fontes et al. (2005b) also reported a $\mathrm{k}_{\mathrm{m}}=63 \%$ for $3 / 4$ Gir-Holstein steers grazing elephant grass.

The efficiency of use of ME for gain $\left(\mathrm{k}_{\mathrm{g}}\right)$ was higher $(\mathrm{P}<0.05)$ in Nellore (0.39) than in crossbred (0.33) (Table 1$)$. According to NRC (1981), the value of $\mathrm{k}_{\mathrm{g}}$ has a positive relationship with the energy density of the diet and the proportion of fat in empty body tissue gain. The average for Nellore and crossbred animals $(\mathrm{kg}=0.36)$ confirms the quality of forage in the experimental conditions (ARC, 1980), being close to the value of 0.37 , reported by Fontes et al. (2005b).

The net energy requirement for gain $\left(\mathrm{NE}_{\mathrm{g}}\right)$ can be decomposed into two components: the energy deposited as fat $\left(\mathrm{NE}_{\mathrm{f}}\right)$ and protein $\left(\mathrm{NE}_{\mathrm{p}}\right)$, so that $\mathrm{NE}_{\mathrm{g}}=\mathrm{NE}_{\mathrm{f}}+\mathrm{NE} \mathrm{p}_{\mathrm{p}}$ (NRC, 1981). However, the efficiencies of ME utilization for fat $\left(\mathrm{k}_{\mathrm{f}}\right)$ and protein $\left(\mathrm{k}_{\mathrm{p}}\right)$ depositions are not equal. By reviewing this subject, Owens et al. (1993) found mean values ( $\pm \mathrm{SE}$ ) of $0.76 \pm 0.08$ and $0.47 \pm 0.20$ for $\mathrm{k}_{\mathrm{f}}$ and $\mathrm{k}_{\mathrm{p}}$, respectively. Since $\mathrm{k}_{\mathrm{f}}>\mathrm{k}_{\mathrm{p}}$, the value of $\mathrm{k}_{\mathrm{g}}$ is not constant, but it varies with the composition of gain (NRC, 1981).

In this study, by considering the reference and ad libitum groups, the average of the DM composition of empty body tissue gain of Nellore and crossbred were 65 and 51\% (fat) and 19 and 32\% (protein), respectively. These differences in composition of gain were probably responsible for greater efficiency $\left(\mathrm{k}_{\mathrm{g}}\right)$ of Nellore in relation to crossbreed.

The NRC (2000) incorporates in energetic value of food the efficiency of use of EM $\left(\mathrm{k}_{\mathrm{m}}\right.$ and $\left.\mathrm{k}_{\mathrm{g}}\right)$ in as much as it expresses the concentrations of net energy for 
maintenance $\left(\left[\mathrm{NE}_{\mathrm{m}}\right]\right)$ and gain $\left(\left[\mathrm{NE}_{\mathrm{g}}\right]\right)$. In this study, $\left[\mathrm{NE}_{\mathrm{m}}\right]$ and $\left[\mathrm{NE}_{\mathrm{g}}\right.$ ] for Mombasa grass were obtained by multiplying the ME by the efficiency of utilization for maintenance $\left(\mathrm{k}_{\mathrm{m}}\right)$ and gain $\left(\mathrm{k}_{\mathrm{g}}\right)$, respectively (average value for the two genetic groups). Thus, $\left[\mathrm{NE}_{\mathrm{m}}\right]=1.20 \mathrm{Mcal} / \mathrm{kg} \mathrm{DM}$ $(1.91 \mathrm{Mcal} / \mathrm{kg} \mathrm{DM} \times 0.63)$ and $\left[\mathrm{NE}_{\mathrm{g}}\right]=0.69 \mathrm{Mcal} / \mathrm{kg} \mathrm{DM}$ (1.91 Mcal/kg DM × 0.36).

In the NRC (2000), the elephant grass at 30 days of regrowth is tabulated with the values of $\left[\mathrm{NE}_{\mathrm{m}}\right]=1.14 \mathrm{Mcal} / \mathrm{kg}$ $\mathrm{DM}$ and $\left[\mathrm{NE}_{\mathrm{g}}\right]=0.58 \mathrm{Mcal} / \mathrm{kg} \mathrm{DM}$. In Brazil, Fontes et al. (2005b) estimated the energy content of elephant grass under grazing also by using the comparative slaughter method. These authors observed values of $\left[\mathrm{NE}_{\mathrm{m}}\right]=$ $1.03 \mathrm{Mcal} / \mathrm{kg} \mathrm{DM}$ and $\left[\mathrm{NE}_{\mathrm{g}}\right]=0.59 \mathrm{Mcal} / \mathrm{kg} \mathrm{DM}$.

\section{Conclusions}

The energy requirements for maintenance does not differ between Nellore and crossbred European-Nellore steers under grazing. For the same body weight, Nellore has a higher proportion of fat in the composition of gain compared to European-Nellore crossbred.

\section{Acknowledgments}

To the staff of UENF Antonio Pereira de Souza, Cristiano Ferreira Moço, Sergio Ribeiro Americo Morais and Eliziel Borges Barbosa, who made the realization of this work possible.

\section{References}

AGRICULTURAL RESEARCH COUNCIL - ARC. The nutrient requirements of ruminants. London: 1980 . 351p.

BRASIL. Ministério da Agricultura. Instrução Normativa no․ 3, de 07 de janeiro de 2000. Regulamento técnico de métodos de insensibilização para o abate humanitário de animais de açougue. S.D.A./M.A.A. Diário Oficial da União, Brasília, p.14-16, 24 de janeiro de 2000, Seção I. Disponível em: <www.agricultura.gov.br/das/dipoa/anexo\%20Abate.htm> Acesso em: 6/5/2008.

COMMONWEALTH SCIENTIFIC AND INDUSTRIAL RESEARCH ORGANIZATION - CSIRO. Feeding standards for Australian livestock-ruminants. Victoria: Australia Agricultural Council, 1990. 266p.

DETMANN, E.; ZERVOUDAKIS, J.T.; CABRAL, L.S. et al. Validação de equações preditivas da fração indigestível da fibra em detergente neutro em gramíneas tropicais. Revista Brasileira de Zootecnia, v.33, n.6, p.1866-1875, 2004.

DICOSTANZO, A.; MEISKE, J.C.; PLEGGG, S.D. et al. Withinherd variation in energy utilization for maintenance and gain in beef cows. Journal of Animal Science, v.68, p.2156-2165, 1990

FERRELL, C.L.; JENKINS, T.G. Body composition and energy utilization by steers of diverse genotypes fed a highconcentrate diet during the finishing period: II. angus, boran, brahman, hereford, and tuli sires. Journal of Animal Science, v.76, p.647-657, 1998b.

FERRELL, C.L. Contribution of visceral organs to animal energy expenditures. Journal of Animal Science, v.66 (Suppl. 3), p.23-24, 1988

FONTES, C.A.A.; OLIVEIRA, R.C.; ERBESDOBLER, E.D. et al. Conteúdo de energia líquida para mantença e ganho do capimelefante e mudanças na composição corporal de novilhos em pastejo, durante a estação chuvosa. Revista Brasileira de Zootecnia, v.34, n.5, p.1711-1720, 2005b.

FONTES, C.A.A.; OLIVEIRA, R.C.; ERBESDOBLER, E.D. et al. Uso do abate comparativo na determinação da exigência de energia de mantença de gado de corte pastejando capim-elefante: descrição da metodologia e dos resultados. Revista Brasileira de Zootecnia, v.34, n.5, p.1721-1729, 2005a.

FONTES, C.A.A. Composição corporal, exigências líquidas de nutrientes para ganho de peso e desempenho produtivo de animais zebuinos e mestiços europeu - zebu. Resultados experimentais. In: SIMPÓSIO INTERNACIONAL SOBRE EXIGÊNCIAS NUTRICIONAIS DE RUMINANTES, 1995 , Viçosa, MG. Anais... Viçosa, MG: JARD, 1995. p.419-455.

FOX, D.G.; TEDESCHI, L.O.; TYLUTKI, T.P. et al. The Cornell Net Carbohydrate and Protein System model for evaluating herd nutrition and nutrient excretion. Animal Feed Science and Technology, v.112, p.29-78, 2004.

FREITAS, J.A.; QUEIROZ, A.C.; DUTRA, A.R. et al. Composição corporal e exigências de energia de mantença em bovinos Nelore, puros mestiços, em confinamento. Revista Brasileira de Zootecnia, v.35, n.3, p.878-885, 2006.

GARRETT, W.N. Factors influencing energetic efficiency of beef production. Journal of Animal Science, v.51, p.1034-1440, 1980.

GESUALDI JÚNIOR, A.; QUEIROZ, A.C.; RESENDE, F.D. et al. Validação dos sistemas viçosa, CNCPS e NRC para formulação de dietas para bovinos nelore e caracu, não-castrados, selecionados em condições brasileiras. Revista Brasileira de Zootecnia, v.34, n.3, p.997-1005, 2005.

HENRIQUE, D.S.; VIEIRA, R.A.M.; MALAFAIA, P.A.M. et al. Estimation of the total efficiency of metabolizable energy utilization for maintenance and growth by cattle in tropical conditions. Revista Brasileira de Zootecnia, v.34, n.3, p.1006-1016, 2005.

JENKINS, T.G.; FERRELL, C.L. Productivity through weaning of nine breeds of cattle under varying feed availabilities: I. Initial evaluation. Journal of Animal Science, v.57, n.11, p.2787-2797, 1994.

JOHNSON, D.E.; KRISTEN, J.A.; BALDWIN, R.L. Changes in liver and gastrointestinal tract energy demands in response to physiological workload in ruminants. Journal of Nutrition, v.120, n. 11, p.649-655, 1990.

LOFGREEN, G.P.; GARRETT, W.N. A system for expressing net energy requeriments and feed values for growing and finishing beef cattle. Journal of Animal Science, v.27, n.3, p.793-806, 1968.

MARTIN, P.C.; GARCIA, R. Growth of 3/4 zebu 1/4 Holstein males under grazing. Energy balance and maintenance requirement. Cuban Journal of Agricultural Science, v.29, n.2, p.305-310, 1995.

NATIONAL RESEARCH COUNCIL - NRC. Nutrient requirement of beef cattle. 7.ed. update. Washington, D.C.: National Academy Press, 2000. 247p.

NATIONAL RESEARCH COUNCIL - NRC. Nutritional energetics of domestic animals \& Glossary of energy terms. 2.ed. Washington: National Academy Press, 1981. 54p.

OSUJI, P.O. The physiology of eating and the energy expenditure of the ruminant at pasture. Journal of Range Management, v.27, n.6, p.437-433, 1974

OWENS, F.N.; DUBESKI, P.; HANSON, C.F. Factors that the growth and development of ruminants. Journal of Animal Science, v.71, n.11, p.3138-3150, 1993. 
POPPI, D.P.; McLENNAN, S.R. Protein and energy utilization by ruminants at pasture. Journal of Animal Science, v.73, n.1, p.278-290, 1995.

RIBEIRO, E.G.; FONTES, C.A.A; PALIERAQUi, J.G.B. et al., Influência da irrigação, durante as épocas seca e chuvosa, na taxa de lotação, consumo e desempenho de novilhos em pastagens dos capim-elefante e capim-mombaça. Revista Brasileira de Zootecnia, v.37, n.9, p.1546-1554, 2008.

SALIBA, E.O.S.; FERREIRA, W.M.; PEREIRA, R.A.N. et al. Lignin from Eucalyptus grandis as indicator for rabbits in digestibility trials. Tropical and Subtropical Agroecosystems, v.3, n.3, p.107-109, 2003.

SANT'ANA, N.F.; FONTES, C.A.A.; SILVA, R.S.T. Body composition and net requirements of protein and energy for weight gain of
Nellore and crossbreed steers finished under grazing. Revista Brasileira de Zootecnia, v.40, n.4, p.912-921, 2011.

SIQUEIRA, J.G.; FONTES, C.A.A.; PEREIRA, A.L. et al. Exigência de energia de mantença e composição corporal e do ganho de vacas de corte adultas de três grupos genéticos confinadas. Revista Brasileira de Zootecnia, v.36, n.6 (supl.), p.2159-2167, 2007.

SMITH, A.M.; REID, J.T. Use of chromic oxide as an indicator of fecal output for the purpose of determining the intake of pasture herbage by grazing cows. Journal of Dairy Science, v.38, n.5, p.515-524, 1955.

TEDESCHI, L.O.; BOIN, C.; FOX, D.G. et al. Energy requirement for maintenance and growth of Nellore bulls and steers fed high-forage diets. Journal of Animal Science, v.80, n.6, p.1671-1682, 2002. 